\title{
The effect of land uses to change on infiltration capacity and surface runoff at latung sub watershed, Padang City Indonesia
}

\author{
Rusli HAR $^{1}$, Aprisal ${ }^{*}$, Werry Darta Taifur ${ }^{3}$, and Teguh Haria Aditia Putra ${ }^{4}$ \\ ${ }^{1}$ Doctoral Program in Agricultural Science, Andalas University, Indonesia \\ ${ }^{2}$ Department of Soil Science, Andalas University, Indonesia \\ ${ }^{3}$ Department of Economics, Andalas University, Indonesia \\ ${ }^{4}$ Department of Forestry, Muhammadiyah University of Sumatera Barat, Indonesia
}

\begin{abstract}
Changes in land use in the Air Dingin watershed (DAS) area in Padang City, Indonesia, lead to a decrease in rainwater infiltration volume to the ground. Some land use in the Latung sub-watershed decrease in infiltration capacity with an increase in surface runoff. This research aims to determine the effect of landuse changes on infiltration capacity and surface runoff. Purposive sampling method was used in this research. The infiltration capacity was measured directly in the field using a double-ring infiltrometer, and the data was processed using the Horton model. The obtained capacity was quantitatively classified using infiltration zoning. Meanwhile, the Hydrologic Engineering Center - Hydrology Modeling System with the Synthetic Unit Hydrograph- Soil Conservation Service - Curve Number method was used to analyze the runoff discharge. The results showed that from the 13 measurement points carried out, the infiltration capacity ranges from $0.082-0.70 \mathrm{~cm} /$ minute or an average of $0.398 \mathrm{~cm} /$ minute, while the rainwater volume is approximately $150,000 \mathrm{~m} 3 /$ hour $/ \mathrm{km} 2$. Therefore, the soil infiltration capacity in the Latung sub-watershed is in zone VI-B or very low. This condition had an impact on changes in runoff discharge in this area, from $87.84 \mathrm{~m} 3 / \mathrm{second}$ in 2010 to $112.8 \mathrm{~m} 3 / \mathrm{second}$ in 2020 or a nail of $22.13 \%$. Based on the results, it is concluded that changes in the land led to low soil infiltration capacity, thereby leading to an increase in surface runoff. Keyword: Land use, infiltration, runoff, Watershed.
\end{abstract}

\section{Introduction}

Padang City has a high population growth rate and development in various sectors within the Air Dingin watershed (DAS) area, which has the Latung subwatershed. Over the past decades, this area has continuously experienced changes in land use with the development of residential, tourist and cultivation areas $[1,3]$. These changes occur in urban, cultivation, and protected areas, thereby decreasing rainwater infiltration into the ground [4]. Furthermore, these changes increase the volume of surface runoff $[4,5]$, erosion and sedimentation [2], inundation, and flooding in the middle and downstream parts of the watershed. This phenomenon occurs due to the inability of the river to accommodate high rainfall.

Air Dingin Watershed has several tributaries with Batang Air Dingin, which acts as the main river despite being dendritic and short in size [2]. The water source comes from the Bukit Barisan Mountains area, located between Solok Regency and east of Padang City, and empties into the Indian Ocean. The network of water and sediment supply channels to the main Batang Air Dingin river occupies a 1,200-hectare mountain range [3,4]. One of the tributaries of this river is the Latung River which later became a part of its watershed with an area of approximately $19.2 \mathrm{~km}^{2}$.

The Latung Sub-watershed area consists of the Koto Tangah Sub-district. This area was designated as the Government Center of Padang City on April 18, 2011, as a transition from the West Padang sub-district based on Government Regulation No. 26 of 2011. The transition made the Latung Sub-watershed experience changes in land use from green open land into residencies, government offices, and other public facilities. These changes decreased the soil's physical properties, such as infiltration capacity, thereby increasing the surface runoff [5].

In 2016 there was a major flood in the Padang city and the Koto Tangah Sub-district, located in the Latung Subwatershed area. This tragedy became evidence that changes in land use of the Latung sub-watershed lead to increased surface runoff discharge [6]. Besides, during the dry season, this area experiences a decreased groundwater absorption. Water deficit occurs in February and April $3.26 \mathrm{~mm} / \mathrm{month}$ and $-43.01 \mathrm{~mm} / \mathrm{month}$, respectively. This means that water does not fill into the aquifer system in the Latung sub-watershed $[1,3,7]$.

\footnotetext{
*Corresponding Author: aprisal@agr.unand.ac.id
} 
Therefore, based on the problems above, it is necessary to examine the infiltration capacity of this area. Infiltration capacity is the vertical entry of water into an initially unsaturated soil under the influence of the soil matrix and gravity suction. The infiltration rate is usually high at the initial stage, however, with the entry of deeper water and a wet soil profile [8], the soil matrix suction decreases. The gravitational pull affects the water movement $[12,13]$, thereby causing the infiltration rate to decrease approaching equilibrium conditions [13, 14]. In line with this problem, Hutasoit (2009) divided the zoning of the infiltration area based on its capacity [9, 11], as shown in Table 1.

Table 1. Zoning Division of Infiltration Areas Based on Capacity

\begin{tabular}{|c|c|c|c|c|}
\hline Zone & \multicolumn{2}{|c|}{$\begin{array}{c}\text { Classification of } \\
\text { Infiltration Areas }\end{array}$} & $\begin{array}{l}\text { Infiltration Rate } \\
\text { (cm/minute) }\end{array}$ & $\begin{array}{l}\text { The Volume of Water } \\
\text { that can be Infused } \\
\left(\mathrm{m}^{3} / \mathrm{hour} / \mathrm{km}^{2}\right)\end{array}$ \\
\hline $\bar{I}$ & \multicolumn{2}{|c|}{ Sangat Tinggi } & $>1.5$ & $1,050,000.00$ \\
\hline II & \multicolumn{2}{|c|}{ Tinggi } & $1.25-1.50$ & $825,013.00$ \\
\hline III & \multicolumn{2}{|c|}{ Agak Tinggi } & $1.00-1.25$ & $675,000.00$ \\
\hline IV & \multicolumn{2}{|c|}{ Sedang } & $0.75-1.00$ & $525,000.00$ \\
\hline \multirow{2}{*}{$\mathrm{V}$} & \multicolumn{2}{|c|}{ Rendah } & $0.50-0.75$ & \multirow{2}{*}{$375,000.00$} \\
\hline & \multicolumn{2}{|c|}{\begin{tabular}{|l|} 
Sangat Rendah \\
\end{tabular}} & $<0.50$ & \\
\hline \multirow{5}{*}{ VI } & 1 & Zona A & $0.40-0.50$ & \multirow{5}{*}{$150,000.00$} \\
\hline & 2 & Zona B & $0.30-0.40$ & \\
\hline & 3 & Zona $\mathrm{C}$ & $0.20-0.30$ & \\
\hline & 4 & Zona D & $0.10-0.20$ & \\
\hline & 5 & Zona $\mathrm{E}$ & $<0.10$ & \\
\hline
\end{tabular}

This research aims to examine the soil infiltration capacity based on the actual infiltration value. Furthermore, it also aims to determine the value of changes in the Latung Sub-watershed surface runoff from 2010 to 2020 .

\section{Methodology}

\subsection{Description of Research Area}

The research was conducted in the Latung Sub-watershed, part of the Air Dingin Watershed of Padang City, Indonesia. This area is geographically located between $0^{\circ}$ $49^{\prime} 01.1^{\prime \prime}$ - $0^{\circ}$ 50' 34" South Latitude and $100^{\circ} 23^{\prime} 38.3^{\prime \prime}$ $100^{\circ} 25^{\prime} 58.8^{\prime \prime}$ East Longitude, at an altitude of 20 - 1,625 $\mathrm{m}$ asl.

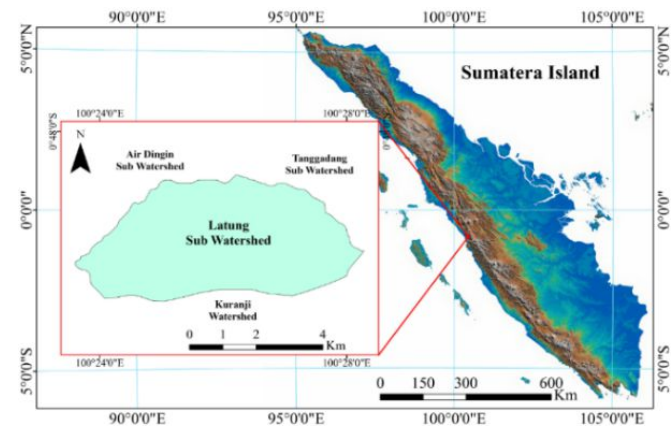

Fig.1. Map of research location

It is bordered by the Air Dingin, Batang Kuranji, and Tanggadang sub-watersheds in the north, south, and Northeast, respectively. The research area is $\pm 19.20 \mathrm{~km}^{2}$ with sloping to steep topography. Based on the Schmidt
Ferguson classification, the climate is classified as type A with an average rainfall of $3,411.8 \mathrm{~mm} /$ year. The is consists of an Inceptisol soil type, therefore the land is used for rice fields, mixed gardens, residencies, as well as secondary and primary forest. The location and condition of the research area are shown in Fig. 1.

\subsection{Data Collection}

The rainfall data were collected from the 3 stations closest to the Latung sub-watershed in the Batang Air Dingin watershed, namely Muaro Panjalinan, Kasang, and Bandung Koto Tuo. Meanwhile, the data on topographic, land use, and soil types were descriptively obtained from spatial and GIS and compared with survey results in the field. A double-ring infiltrometer was used to analyze the data randomly collected from 13 points in the field. This tool is made of steel with an inner circle of $30 \mathrm{~cm}$, an outer circle of $60 \mathrm{~cm}$, and a height of $30 \mathrm{~cm}$.

\subsection{Data Analysis}

\subsubsection{Spatial data analysis}

Data on topography, land use, and soil types were used as the basis for determining the flow coefficient for the HECHMS modeling (HSS SCS CN method) [18]. The data were mainly used to determine the runoff coefficient (C) and the Curve Number $(\mathrm{CN})$ value in the Latung subwatershed and analyzed with ArcGIS 10.6.

\subsubsection{Infiltration data analysis}

Factors affecting infiltration include the influence of soil properties, cover crops, water content, rainfall, etc. The Horton method was used to calculate the infiltration capacity, which was dependent on natural parameters in the field. However, a mathematical approach or deterministic statistics is used to carry out the Horton equation assuming the data taken in the field is not accompanied by natural parameters [10-12]. This process is carried out by analyzing the trend of the data obtained from the measurement results in the field due to the influence of natural parameters. The infiltration rate is calculated based on the Horton model with equation (1).

Where $\boldsymbol{f}$ is infiltration capacity (cm/hour), $\boldsymbol{f}_{\boldsymbol{o}}$ is the initial infiltration rate (cm/hour), $f_{c}$ is the constant infiltration rate in a certain time interval $\boldsymbol{t}$ during the test (cm/hour), $\boldsymbol{K}$ is a constant, $\boldsymbol{t}$ is time (hours) and $\boldsymbol{e}$ is exponential number $=2,718$. The process of determining the value of $\mathrm{K}$ in Equation (1) is derived as follows:

$$
\begin{aligned}
f & =f_{c}+\left(f_{0}-f_{c}\right) e^{-K t} \\
f-f_{c} & =\left(f_{o}-f_{c}\right) e^{-K t}
\end{aligned}
$$

The log of both sides of Equation (2) is as follows:

$$
\begin{aligned}
& \log \left(f-f_{c}\right)=\log \left(f_{o}-f_{c}\right)-K t \log e \\
& \log \left(f-f_{c}\right)-\log \left(f_{o}-f_{c}\right)=-K t \log e \\
& t=-\frac{1}{K \log e}\left[\log \left(f-f_{c}\right)-\log \left(f_{o}-f_{c}\right)\right]
\end{aligned}
$$




$$
t=-\frac{1}{K \log e} \log \left(f-f_{c}\right)+\frac{1}{K \log e} \log \left(f_{o}-f_{c}\right)
$$

To determine the unknown parameters from Equation (3), a comparison is made with a linear equation in the form: $\boldsymbol{y}=\boldsymbol{m} \boldsymbol{x}+\boldsymbol{c}$, where $\mathrm{y}=\mathrm{f}, m=-\frac{1}{K \log e}, x=\log \left(f-f_{c}\right)$ and $c=\frac{1}{K \log e} \log \left(f_{o}-f_{c}\right)$.

Therefore, the value of $\mathrm{K}$ is determined as follows:

$$
\begin{aligned}
& m=-\frac{1}{K \log e} \\
& K=-\frac{1}{m \log e}=-\frac{1}{m \log 2,718} \\
& K=-\frac{1}{0,434 m}
\end{aligned}
$$

Where $m$ is the gradient obtained from the linear graph of the relationship between time $(t)$ and $\log (f-F C)$. Meanwhile, the initial infiltration value $\left(f_{o}\right)$ is calculated from the regression equation generated from the graph plot of the infiltration capacity $(f)$ against time $(t)$. The regression equation model used to produce $f_{o}>$ FC provides the largest correlation coefficient $(r)$ and determination coefficient $\left(\mathrm{R}^{2}\right)$.

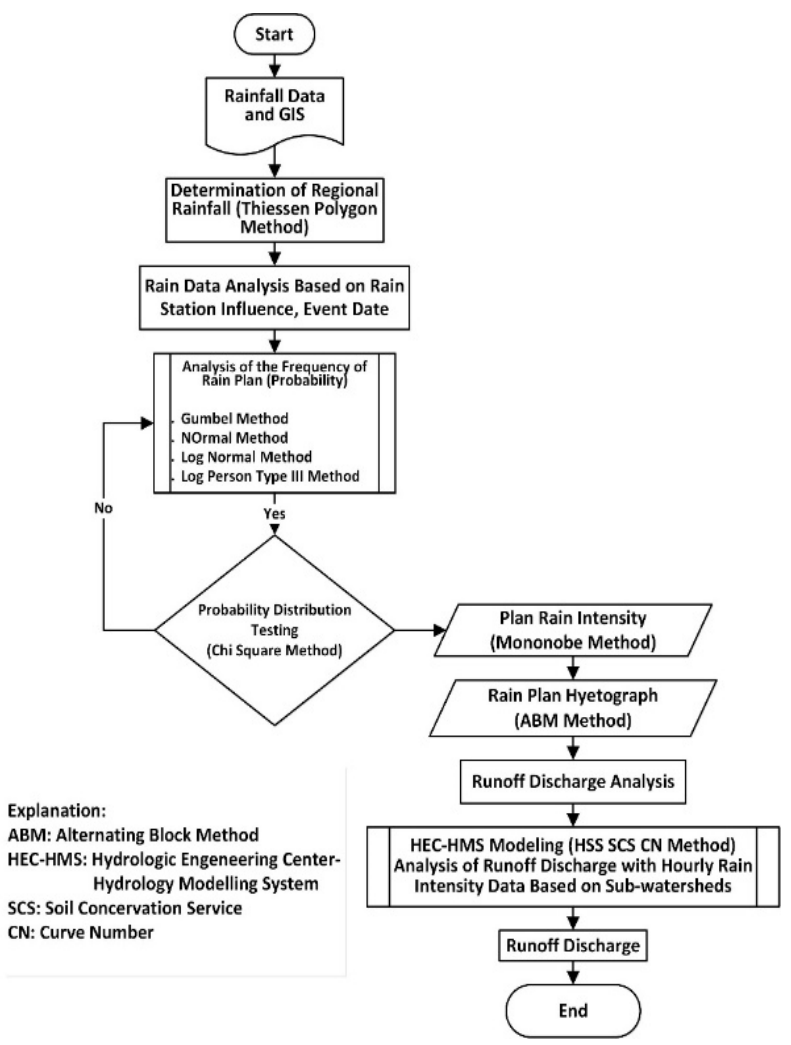

Fig. 2. Flowchart of Analysis on Rainfall and Runoff Discharge in Latung Sub-watershed

\subsubsection{Analysis of rainfall and runoff discharge data}

The process of examining the rainfall Influence from the 3 closest stations to the Latung sub-watershed was performed using the Thiessen Polygon method, as shown in Fig. 6. Rainfall around the Latung sub-watershed enters the tributaries and then flows and accumulates into the main river, which is the basis for calculating runoff. Furthermore, the Mononobe method was used to obtain the value of the planned rainfall intensity, which was also used to determine the peak discharge value described in the form of an IDF (Intensity Duration Frequency) curve $[15,16]$. The Mononobe method was an IDF curve regression equation were used to determine the rainfall data.

The runoff flow is directly generated from the analysis of the effective rainfall calculated by the Soil Conservation Service Curve Number (SCS-CN) Method $[17,18]$, where the rain falling on the surface is reduced by losses due to abstraction during surface runoff. Furthermore, the HEC-HMS modeling (HSS SCS CN method) $[17,18]$ was used to analyze the runoff discharge, using the Hydrologic Engineering Center Modeling Hydrology Modeling System (with Synthetic Unit Hydrograph - Soil Conservation Service - Curve Number) method. Meanwhile, the runoff coefficient (C) for each land cover was calculated using equation (5):

$$
C_{D A S}=\frac{\sum_{i=1}^{n} C_{i} A_{i}}{\sum_{i=1}^{n} A_{i}}
$$

Where $\mathrm{C} i$ is the coefficient of surface runoff of land cover $\mathrm{I}, \mathrm{A} i$ is the area with land cover $i$. The concentration-time (tc) is calculated using the Kirpich Equation (Kamiana, 2011) (6)

$$
t_{c}=\left(\frac{0,87 \times L^{2}}{1000 \times S}\right)^{0,385}
$$

Where tc is the concentration-time (hours), L is the river length $(\mathrm{km})$, and $\mathrm{S}$ is the gradient. In this method, the runoff discharge analysis used hourly rainfall intensity data based on the sub-watersheds in the research area. The sequence in analyzing rainfall to runoff discharge in the Latung sub-watershed is shown in Fig. 2.

\section{Results and Discussion}

\subsection{Topography of Research Area}

The topography of the Latung Sub-watershed area is shown in Fig. 3. Generally, the topographic conditions in the north bordering the Air Dingin Sub-watershed are quite steep to sloping. The Air Dingin and the Tanggadang Sub-watershed have a very steep topography in the Northeast and south. Meanwhile, in the east and west, the topography is quite steep to sloping, which becomes the basis for the calculation of runoff discharge.

\subsection{Land Use}

Fig. 4 shows the land use of the Latung Sub-watershed area. The figure explains that this area borders the Air Dingin and the Tanggadang Sub-watershed in the north and consists of mixed forests and gardens. To the east, it is bordered by a forest area including protected forest, while to the west, it is an area of mixed gardens and shrubs. Furthermore, the Batang Kuranji watershed is 
bordered to the south and is an area of mixed gardens and secondary forest. This land-use condition is also the basis for the calculation of runoff discharge.

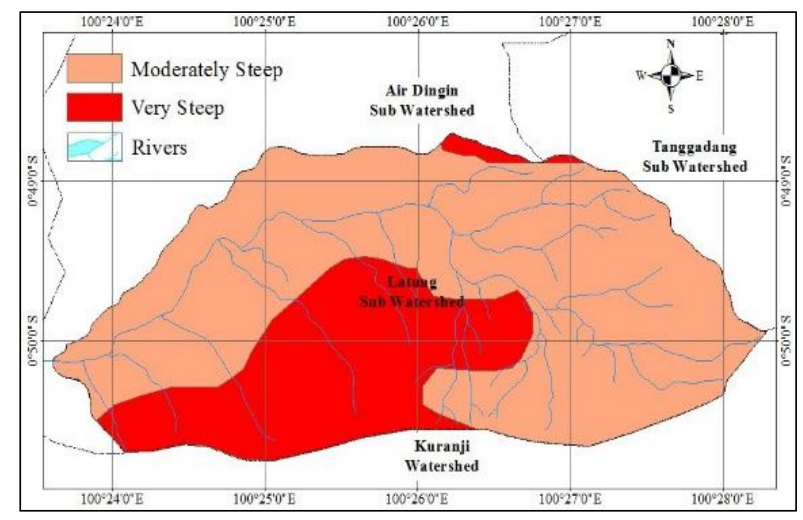

Fig. 3. Topographical Conditions of Research Area

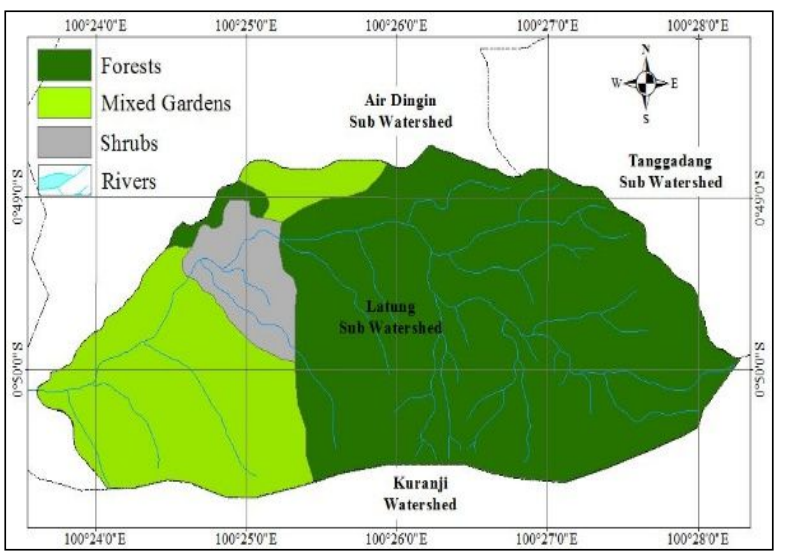

Fig. 4. Conditions of Land Use in the Latung Sub-watershed Area

\subsection{Soil Type}

The soil type in the Latung sub-watershed area is shown in Fig. 5, where it is mostly dominated by Humitropepts, namely Tropepts sub-order of Inceptisol rich in humus. In the western part of the Latung sub-watershed, the soil types are divided into 2, namely Dystropepts and Tropaquepts. Dystropepts are soils with base saturation below $50 \%$, with medium to very deep depths, fine to medium texture, acidic to very acidic soil reactions, and poor in nutrients or low soil fertility. Meanwhile, Tropaquepts are a great group of the Aquepts sub-order and the Inceptisols. This soil type does not have sulfidic material at a depth below $50 \mathrm{~cm}$ from the mineral soil surface and has an isometric soil temperature. It is also used as a basis for determining runoff discharge in the Latung sub-watershed.

\subsection{Infiltration Capacity}

The analysis results on infiltration data in the Latung subwatershed are shown in Table 2. The average initial infiltration rate in the research area was $24.85 \mathrm{~cm} /$ hour. Furthermore, the average constant infiltration rate was $23.54 \mathrm{~cm} /$ hour, with an average constant condition of 1.09 hours and an average infiltration capacity of 23.87 $\mathrm{cm} /$ hour, equivalent to $0.3978 \mathrm{~cm} /$ minute. The value of infiltration rate in Latung Sub-watershed is shown in Table 2.

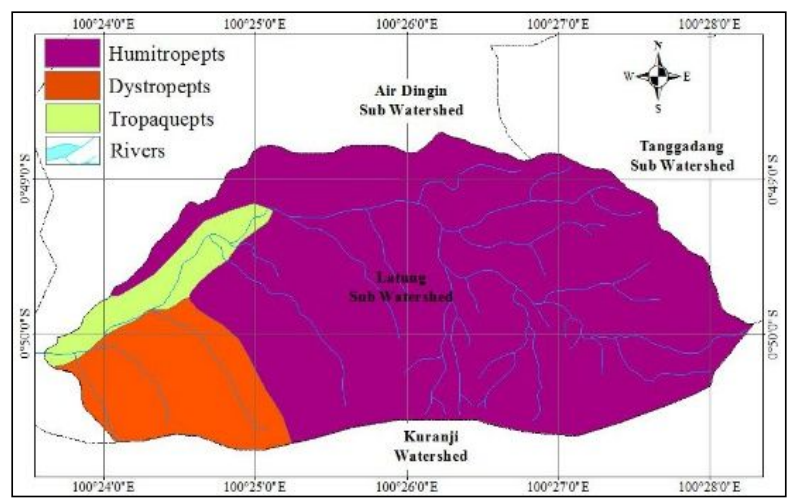

Fig. 5. Soil Types in the Latung Sub-watershed

Table 2. Infiltration Rate in Latung Sub-watershed

\begin{tabular}{|c|c|c|c|c|c|c|c|c|c|c|c|}
\hline \multirow[t]{2}{*}{ No } & \multirow[t]{2}{*}{\begin{tabular}{|l|l} 
Measuring \\
Point
\end{tabular}} & \multirow{2}{*}{ 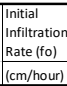 } & \multirow{2}{*}{ 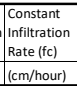 } & \multirow{2}{*}{\begin{tabular}{|l}
$\begin{array}{l}\text { Time } \\
\text { constant } \\
\text { (ft) }\end{array}$ \\
(loclock) \\
\end{tabular}} & \multicolumn{2}{|c|}{ Infiltration Capacity (f) } & \multicolumn{2}{|c|}{$\begin{array}{c}\text { Classificati } \\
\text { on of } \\
\text { Infiltration }\end{array}$} & \multirow{2}{*}{ 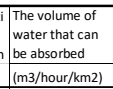 } & \multirow{2}{*}{\begin{tabular}{|l|}
$\begin{array}{l}\text { Latung sub- } \\
\text { watershed } \\
\text { area }\end{array}$ \\
$\mathrm{km} 2$ \\
\end{tabular}} & \multirow{2}{*}{\begin{tabular}{|l|}
$\begin{array}{l}\text { Total debit } \\
\text { absorb }\end{array}$ \\
(m3/hour) \\
\end{tabular}} \\
\hline & & & & & $\mathrm{cm} /$ hour & (cm/minute) & & & & & \\
\hline 1 & Eppt.A.KC & 16.64 & 16.20 & 1.17 & 16.28 & 0.271 & VVI-c & |vL & & & \\
\hline 2 & EPP.A.SB & 23.32 & 22.80 & 1.33 & 22.86 & 0.381 & VI-B & vi & & & \\
\hline 3 & Ept.B.KC & 28.33 & 24.00 & 0.83 & 24.83 & 0.414 & VIA & vL & & & \\
\hline 4 & Ept.B.SB & 30.51 & 30.00 & 1.17 & 30.12 & 0.502 & VIA & vi & & & \\
\hline 5 & Ept.C.НT & 40.16 & 39.00 & 1.50 & 39.00 & 0.65 & v & L & & & \\
\hline 6 & Ept.C.KC & 36.62 & 36.00 & 1.67 & 36.03 & 0.60 & v & L & & & \\
\hline 7 & Ept.C.SB & 42.65 & 42.00 & 1.50 & 42.00 & 0.70 & v & L & 150.00 & 19.20 & $2,880,000$ \\
\hline 8 & Eppt.D.HT & 38.91 & 35.40 & 1.00 & 36.29 & 0.61 & lv & L & & & \\
\hline 9 & Ept.D.KC & $\mid 18.19$ & 18.00 & 1.00 & 18.05 & $\mid 0.31$ & VI-B & vi & & & \\
\hline 10 & Ept.D.SB & 11.64 & 10.80 & 0.83 & 11.00 & 0.18 & VVI-D & vL & & & \\
\hline 11 & Ept.E.HT & 25.06 & 22.20 & 0.67 & 23.80 & 0.39 & V1-B & vi & & & \\
\hline 12 & Ept.E.KC & 5.75 & 4.80 & 0.67 & 5.13 & 0.09 & VI-E & vi & & & \\
\hline 13 & Ept.E.SB & 5.25 & 4.80 & 0.83 & 4.92 & 0.08 & VI-E & vL & & & \\
\hline & & 24,85 & 23.54 & 1.09 & 23.87 & 0.97 & & & & & 2.880 .000 \\
\hline
\end{tabular}

Description, Ept $=$ Inceptisol, A, B, C, D, E = the slope of land, $\mathrm{Kc}=$ mix garden, $\mathrm{SB}=$ shrubs, $\mathrm{HT}=$ forest. $\mathrm{VL}=$ very low, $\mathrm{L}=$ low.

The infiltration capacity of the Latung sub-watershed in Table 2 is in zone VI-B, which is very low compared to the value in Table 1 . The rainwater infiltration capacity was only $150,000 \mathrm{~m}^{3} /$ hour $/ \mathrm{km}^{2}$. Maximum and evenly distributed rain in the entire Latung sub-watershed area has a total infiltration capacity of $2.880,000 \mathrm{~m}^{3}$ in one maximum rainy period, which is much smaller in the dry months. This shows that the infiltration capacity of the Latung Sub-watershed is in a critical condition. In the dry season, where rainfall is very low, the capacity decreases, thereby leading to a water deficit. Preliminary studies showed that the deficit of water infiltration in the Latung sub-watershed occurs in dry months, especially in February (-3.26 mm/month) and April (-43.01 $\mathrm{mm} /$ month) [7]. The main cause of critical infiltration is the burden on the sub-watershed. Especially in the upstream part, which keeps increasing due to changes in land use.

The infiltration capacity of the Latung sub-watershed in Table 2 is in zone VI-B, which is very low compared to the value in Table 1 . The rainwater infiltration capacity was only $150,000 \mathrm{~m}^{3} / \mathrm{hour} / \mathrm{km}^{2}$. Maximum and evenly distributed rain in the entire Latung sub-watershed area has a total infiltration capacity of $2.880,000 \mathrm{~m}^{3}$ in one maximum rainy period, which is much smaller in the dry months. This shows that the infiltration capacity of the 
Latung Sub-watershed is in a critical condition. In the dry season, where rainfall is very low, the capacity decreases, thereby leading to a water deficit. Preliminary studies showed that the deficit of water infiltration in the Latung sub-watershed occurs in dry months, especially in February (-3.26 mm/month) and April (-43.01 $\mathrm{mm} / \mathrm{month}$ ) [7]. The main cause of critical infiltration is the burden on the sub-watershed. Especially in the upstream part, which keeps increasing due to changes in land use.

\subsection{Analysis of Rainfall and Runoff Discharge}

Based on the analysis of regional rainfall using the Thiessen Polygon method, it is known that the area of the Batang Air Dingin Watershed is $131.18 \mathrm{~km}^{2}$. Meanwhile, the Latung sub-watershed is $19.20 \mathrm{~km}^{2}$ or $14.6 \%$ of the total area of the Batang Air Dingin watershed. Therefore, the area of rainfall influence in the Latung sub-watershed is $14.6 \%$ of the total rainfall Influence on the Batang Air Dingin watershed. Fig. 6 and Table 3 show that the total area of rainfall Influence from the 3 existing rain gauge stations on the Latung sub-watershed is $19.2 \mathrm{~km}^{2}$.

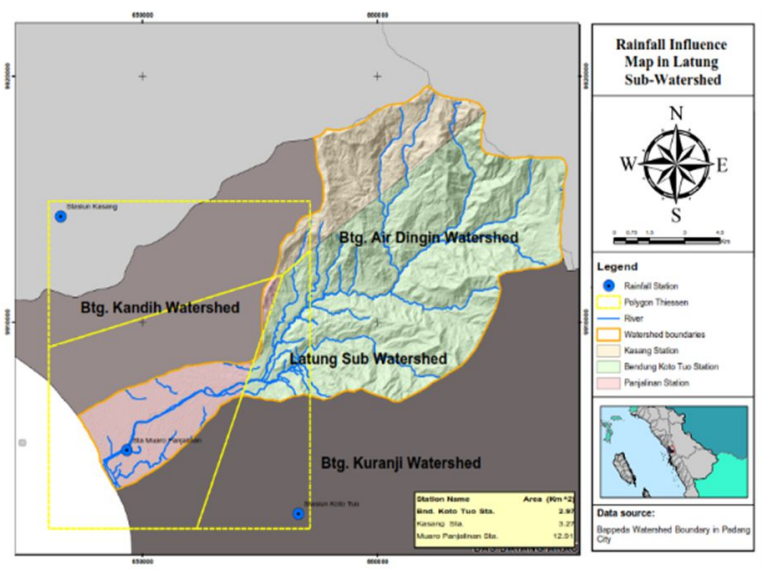

Fig. 6. Rainfall Influence on Latung Sub-watershed with Polygon Thiessen Method

Table 3. The Rainfall Influence on the Latung Sub-watershed

\begin{tabular}{|l|c|c|}
\hline \multicolumn{1}{|c|}{ Station } & $\begin{array}{c}\text { Rainfall Influence Area } \\
\left(\mathbf{k m}^{2}\right)\end{array}$ & $\%$ \\
\hline Muaro Panjalinan Station & 2.97 & 15.50 \\
\hline Kasang Station & 3.27 & 17.08 \\
\hline Bendung Koto Tuo Station & 12.92 & 67.42 \\
\hline \multicolumn{1}{|c|}{ Total } & $\mathbf{1 9 . 1 6}$ & $\mathbf{1 0 0 . 0 0}$ \\
\hline
\end{tabular}

Based on the sequence of the analysis process shown in Fig. 2, the planned rainfall intensity in the Latung Subwatershed area calculated under 5, 10, 20, 25, 50, and 100 year return periods is described in the form of an IDF (Intensity Duration Frequency) curve [15,16]. The analysis is shown in Fig. 7.

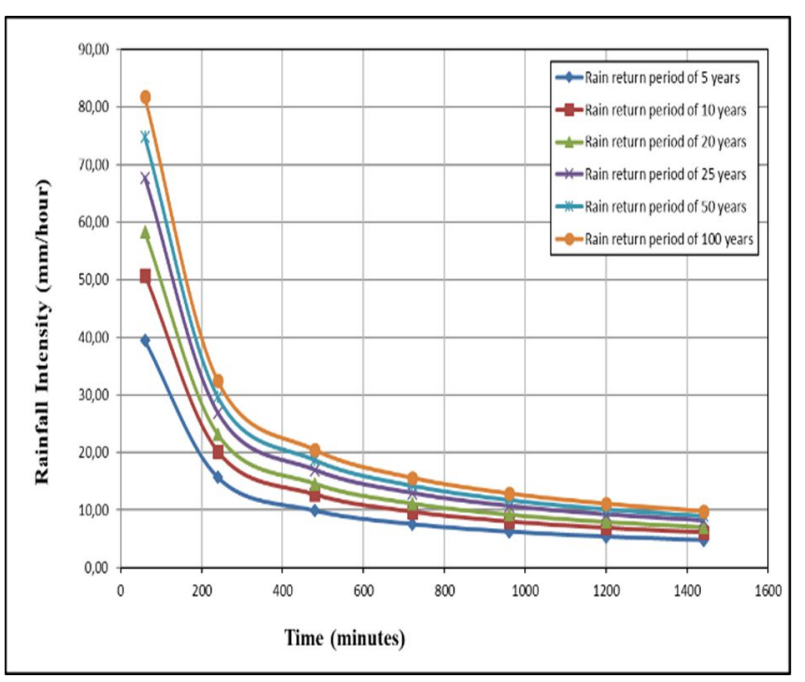

Fig. 7. IDF (Intensity Duration Frequency) Curve with Return Period in Latung Sub-watershed

\subsection{Analysis of Runoff Discharge}

The runoff coefficient value, Curve Number $(\mathrm{CN})$, Land Use, and runoff discharge in the Latung sub-watershed are highly dependent on the type and area of land use, as shown in Figs. 3, 4, and 5. Meanwhile, the concentrationtime (tc) is the time needed to drain rainwater from the farthest point to flow over the ground to a certain point in terms of the drainage area. The time is influenced by the characteristics of the infiltration area, land use, and the distance of the water path from the farthest to the consideration point. According to the existing data,

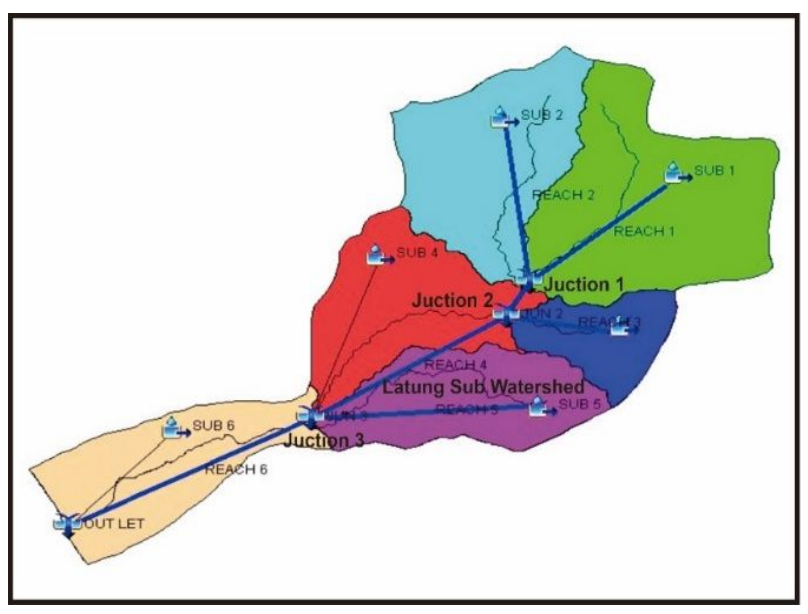

Fig. 8. Junction 3 of the Latung Sub-Watershed

The concentration-time (tc) in the Latung River calculated using equation (6) is 2.61 hours. Fig. 7 provides a detailed analysis of the runoff discharged in the Batang Air Dingin Watershed, which is divided into 6 subwatersheds, while runoff is divided into 3 junctions. The 3rd junction is the accumulation of runoff discharge originating from the Latung sub-watershed, as shown in Fig. 8. 
Table 4. Analysis Results of Runoff Discharge in Latung Subwatershed for Return Period of 25 Years

\begin{tabular}{|c|c|c|c|c|}
\hline \multicolumn{5}{|c|}{ Junction 3 (Repeat Period 25 Years) } \\
\hline Time & $\begin{array}{c}\text { Inflow } \\
\text { From } \\
\text { Junction 2 }\end{array}$ & $\begin{array}{c}\text { Inflow From } \\
\text { Sub 4 }\end{array}$ & $\begin{array}{c}\text { Inflow From } \\
\text { Latung Sub } \\
\text { Watershed }\end{array}$ & $\begin{array}{c}\text { Outflow From } \\
\text { Junction 3 }\end{array}$ \\
\hline Hour & \multicolumn{3}{|c|}{$\left(\mathbf{m}^{\mathbf{3}} / \mathbf{s}\right)$} \\
\hline 0 & 0,0 & 0,0 & 0,0 & 0,0 \\
\hline 2 & 1,1 & 3,9 & 1,4 & 6,3 \\
\hline 4 & 351,5 & 150,1 & $\mathbf{1 1 2 , 8}$ & 614,3 \\
\hline 6 & 269,5 & 78,0 & 75,1 & 422,7 \\
\hline 8 & 170,0 & 47,9 & 45,7 & 263,6 \\
\hline 10 & 125,9 & 37,4 & 34,4 & 197,6 \\
\hline 12 & 104,7 & 31,6 & 28,8 & 165,1 \\
\hline 14 & 48,7 & 8,0 & 11,4 & 68,1 \\
\hline 16 & 16,0 & 1,5 & 3,0 & 20,5 \\
\hline 18 & 4,5 & 0,2 & 0,7 & 5,5 \\
\hline 20 & 1,2 & 0,0 & 0,1 & 1,3 \\
\hline 22 & 0,3 & 0,0 & 0,0 & 0,3 \\
\hline 24 & 0,1 & 0,0 & 0,0 & 0,1 \\
\hline
\end{tabular}

The analysis results are presented seen in Table 4, while the graph of the runoff discharge hydrograph is shown in Fig. 9.

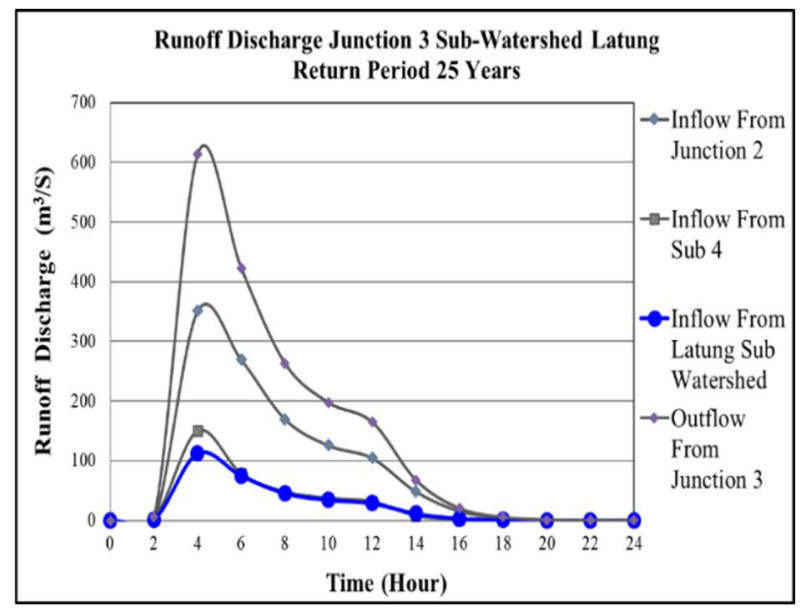

Fig. 9. Hydrograph of runoff discharge into the Latung subwatershed

Fig. 9 and Table 4 are used to explain the preparation of the hydrograph graph for runoff entering the Latung Sub-watershed, the maximum rain duration occurred for 6 hours. The area of the Latung sub-watershed is 19.20 $\mathrm{km}^{2}$ or $14.64 \%$ of the total area of the Batang Air Dingin watershed. Furthermore, based on the runoff discharge analysis, the value of surface runoff in 2020 calculated by the SCS CN method for a 25 year return period in the Latung sub-watershed is $112.8 \mathrm{~m} 3 / \mathrm{second}$, as shown in Table 4. Meanwhile, in $201014.64 \%$ of the design was discharged, for $87.84 \mathrm{~m}^{3} / \mathrm{second} \mathrm{[19].} \mathrm{There} \mathrm{was} \mathrm{an}$ increase in the runoff discharge of $25 \mathrm{~m}^{3} / \mathrm{second}$ or $22.13 \%$ in the years before 2010 . The increase in runoff discharge and the small volume of infiltration in this area were due to the flood disaster in the downstream area of the Latung Sub-watershed, namely in the Muara Penjalinan or the outlet area of the Air Dingin watershed. Therefore, efforts are needed to carry out reclamation or conservation to restore the condition of the Latung subwatershed to maintain its function as a counterweight for the preservation of water resources.

\section{Conclusion}

The following conclusions were obtained from the research results:

1. The infiltration capacity in the Latung sub-watershed for 1.09 hours is $23.87 \mathrm{~cm} /$ hour with a relatively low infiltration capacity of $150,000 \mathrm{~m} 3 /$ hour $/ \mathrm{km}^{2}$.

2. There was an increase in runoff discharge of 25 $\mathrm{m}^{3} /$ second or $22.13 \%$ from 2010 to 2020 .

The authors are grateful to the Chancellor of Andalas University for facilitating the laboratory infrastructure for soil sample analysis, which enabled the adequate conduction of this research. Furthermore, the authors are grateful to the students that helped to measure and take soil samples and analysis in the laboratory. Hopefully, this research can be one of the literary references in science development.

\section{References}

1. Aprisal, Junaidi. The Effect of Land Reclamation on Physical and Erosion Properties in Reeds Land. J. Solum 7 (2) July 2010: 118-123. ISSN: 1829-7994 (2010)

2. Aprisal, Junaidi. Prediction of Erosion and Sedimentation in Various Land Use in the Lake Limau Manis Sub Watershed in the Kuranji River Basin, Padang City. J. Solum 7 (1) January 2010:61-67. (2010)

3. R. HAR, Study on the Potential of Groundwater in the City of Padang and Its Relationship to the 2003/2004 Padang city master plan. Research and Development Agency of West Sumatra Province (2004)

4. T. Aprisal. Dyn. Of. Soil. Phys. Suboptimal Land Journal.2017 (2017).

5. R. HAR, Empowerment of Infiltration Areas as Flood Prevention Efforts, Seen from a Hydrogeological Point of View. Research and Development Agency of West Sumatra Province (2006)

6. West Sumatra Water Resources Management Office. West Sumatra Water Resources Management Profile (2017)

7. R. HAR, Study on Potential, Development, Management, and Zoning of Groundwater in Padang City, Competitive Grant 2014 (2014)

8. D. Hillel, Soil and Water Physical Principles and Processes, Academic Press New York, San Francisco, London (1978)

9. L. M. Hutasoit, Quantitative Study of Water Infiltration in North Bandung Area. LPPM-ITB Bandung (1997)

10. L. M. Hutasoit, Groundwater Surface Conditions with and without artificial infiltration in the Bandung area: Numerical Simulation Results. Indonesian Journal of Geology, 4 (3), 177-188 (2009)

11. L. M. Hutasoit, Land cover variations and their implications for baseline flow values in the Upper Citarum watershed. 2015 National Seminar on Remote Sensing (2015) 
12. C.W. Fetter, Contaminant Hydrogeology, Mac Millan Publishing Company, New York (1993)

13. R. A. Freeze, , and J.A. Cherry. Groundwater, Prentice-Hall, Englewood Cliffs, New Jersey (1979)

14. D. Hillel, Applications of Soil Physics. Academic Press, Inc. Harcourt Brace Jovanovich, Publishers. 1250 Sixth Avenue, Sandiego, California 92101 (1980)

15. Y. Sun, D. Wendi, D.E. Kim, and S.Y. Deriving intensity-duration-frequency (IDF) curves using downscaled in situ rainfall assimilated with remote sensing data. Official Journal of the Asia Oceania Geosciences Society (AOGS (2019).

16. F. De Paola, , M. Giugni, and M. E. Topa, et al. Intensity-Duration-Frequency (IDF) rainfall curves, for data series and climate projection in African cities. SpringerPlus 3, 133 (2014).

17., G. J. Alves, C. R. de Mello, S. Beskow, J.A. Junqueira and M. A. Nearing. Assessment of the Soil Conservation Service-Curve Number method performance in a tropical Oxisol watershed. Journal of Soil and Water Conservation September 2019, 74 (5) 500-512(2019)

18.S. K. Mishra, Singh, and Vijay. Soil Conservation Service Curve Number (SCS-CN) Methodology. Water Science and Technology Library. eBook ISBN 978-94-017-0147-1 (2003)

19.Department of Public Works for Irrigation, West Sumatra Province. Infrastructure Development for Flood Control in Padang City. Padang City Flood Control Project (2000) 